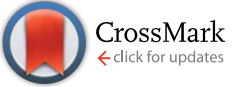

Cite this: RSC Adv., 2017, 7, 10849

2017

Accepted 6th February 2017

DOI: 10.1039/c7ra01143a

rsc.li/rsc-advances

\section{Prenylated phenylpropanoids with unprecedented skeletons from Illicium burmanicum $\dagger$}

\author{
Xinhui Tian, $\stackrel{t}{\mathrm{t}}^{\mathrm{a}}$ Xin Guo, $\stackrel{t}{\mathrm{t}}^{\mathrm{a}}$ Zhiguo Zhuo, ${ }^{\mathrm{b}}$ Rentao Zeng, ${ }^{\mathrm{b}}$ Xin Fang, ${ }^{\mathrm{b}}$ Xike Xu, ${ }^{\mathrm{b}}$ \\ Huiliang Li, ${ }^{\text {b }}$ Yunheng Shen ${ }^{\mathrm{b}}$ and Weidong Zhang*abc
}

A phytochemical investigation on the branches and leaves of Illicium burmanicum led to the isolation of two unique allo-thujane-phenylpropane and lavandulane-phenylpropane hetero-adducts (1 and 2), two new prenylated phenylpropanoids ( 3 and 4 ), and one new neolignan (5). Their structures were established by comprehensive NMR and CD spectroscopic analysis. Burmaniols A (1) and B (2) showed appreciable cytotoxicity against A549 and HCT116 cells with $I_{50}$ values of $6.40-7.76 \mu \mathrm{M}$.

\section{Introduction}

There are approximately 50 species in the genus Illicium, and 28 of which occur exclusively in China. ${ }^{1}$ Illicium plants are rich sources of structurally diverse sesquiterpenoids, lignans and prenylated phenylpropanoids. ${ }^{2-9}$ Plants of the Illicium genus have attracted considerable attention due to their diverse bioactivities such as neurotrophic, ${ }^{4,10-22}$ neurotoxic, ${ }^{23}$ cytotoxic, ${ }^{24}$ cancer chemopreventive, ${ }^{25}$ anti-inflammatory ${ }^{\mathbf{9 2 6 - 2 7}}$ and anti-depressant activities. ${ }^{28}$ Illicium burmanicum E. H. Wilson

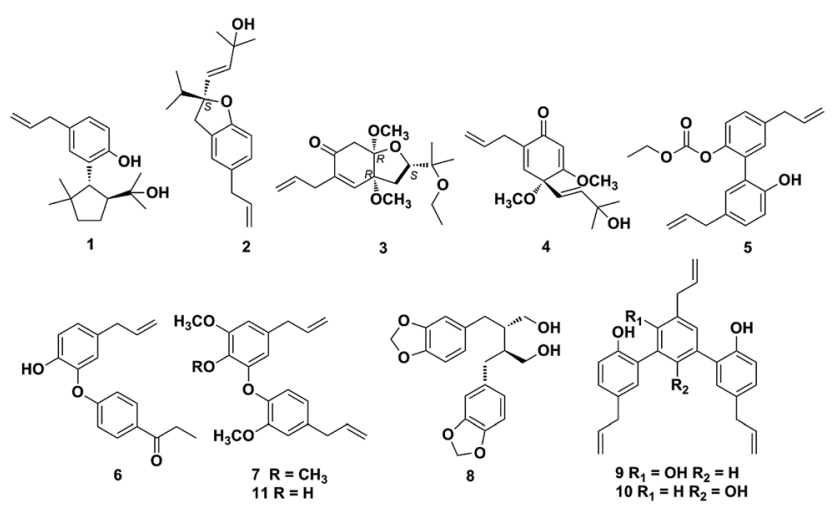

Fig. 1 Chemical structures of compounds 1-11.

\footnotetext{
${ }^{a}$ Interdisciplinary Science Research Institute, Shanghai University of Traditional Chinese Medicine, Shanghai 201203, P. R. China.E-mail:wdzhangy@hotmail.com; Web: http://www.shutcm.edu.cn/

${ }^{b}$ Department of Phytochemistry, School of Pharmacy, Second Military Medical University, Shanghai 200433, P. R. China

'Innovative Research Center of Traditional Chinese Medicine, Shanghai Institute of Pharmaceutical Industry, Shanghai 201204, P. R. China

† Electronic supplementary information (ESI) available. See DOI: 10.1039/c7ra01143a

\$ These authors contributed equally to this work.
}

(Schisandraceae) is an evergreen tree or shrub distributed in Burma and Yunnan province of China. Its roots, leaves, and fruit have been locally used as folk medicine for preventing vomiting, relieving pain, promoting tissue regeneration and setting a broken bone in the southwest of China. ${ }^{29}$ Previously, several new sesquiterpene lactones and prenylated phenylpropanoids with anti-inflammatory activity have been isolated from the stem bark of $I$. burmanicum. ${ }^{9,26}$ In this study further investigation on the branches and leaves of $I$. burmanicum was performed to search for more compounds with novel structures and potent bioactivities. As a result, five new (1-5) and six known compounds (6-11) were isolated from this plant. Herein, the isolation and structural elucidation of compounds 1-11, and their cytotoxic activities against human tumor cell lines are described (Fig. 1).

\section{Results and discussion}

Compound 1 was isolated as white wax. The pseudo-molecular ion peak at $\mathrm{m} / z=287.2022[\mathrm{M}-\mathrm{H}]^{-}$(calcd 287.2011) established the molecular formula of $\mathrm{C}_{19} \mathrm{H}_{28} \mathrm{O}_{2}$. The ${ }^{1} \mathrm{H}$ NMR spectrum showed signals attributed to four methyl groups at $\delta_{\mathrm{H}}=$ $0.74(3 \mathrm{H}, \mathrm{s}), 0.97(3 \mathrm{H}, \mathrm{s}), 0.99(3 \mathrm{H}, \mathrm{s}), 1.13(3 \mathrm{H}, \mathrm{s})$, an allyl group at $\delta_{\mathrm{H}}=3.29(2 \mathrm{H}, \mathrm{d}, J=6.5 \mathrm{~Hz}), 5.00(1 \mathrm{H}, \mathrm{dd}, J=17.0,2.0 \mathrm{~Hz})$, $5.02(1 \mathrm{H}, \mathrm{dd}, J=11.0,2.0 \mathrm{~Hz}), 5.95(1 \mathrm{H}, \mathrm{ddt}, J=17.0,11.0,6.5$ $\mathrm{Hz})$, and a 1,3,4-substituted phenyl group at $\delta_{\mathrm{H}}=6.70(1 \mathrm{H}, \mathrm{d}, J$ $=8.0 \mathrm{~Hz}), 6.85(1 \mathrm{H}, \mathrm{dd}, J=8.0,1.5 \mathrm{~Hz}), 6.99(1 \mathrm{H}, \mathrm{br} \mathrm{s})$. More detailed information about the structure of 1 came from the interpretation of ${ }^{1} \mathrm{H}-{ }^{1} \mathrm{H}$ COSY, HSQC, HMBC, and NOESY spectra. In the ${ }^{1} \mathrm{H}-{ }^{1} \mathrm{H}$ COSY spectrum of 1 , correlations of $8-\mathrm{H}$ $\left(\delta_{\mathrm{H}}=5.95\right)$ with $7-\mathrm{H}_{2}\left(\delta_{\mathrm{H}}=3.29\right)$ and 9- $\mathrm{H}_{2}\left(\delta_{\mathrm{H}}=5.00,5.02\right)$ were observed, whereas $5-\mathrm{H}\left(\delta_{\mathrm{H}}=6.70\right)$ displayed correlation with 6$\mathrm{H}\left(\delta_{\mathrm{H}}=6.85\right)$. The above evidence, together with the key HMBC correlations from $7-\mathrm{H}_{2}$ to $\mathrm{C}-1\left(\delta_{\mathrm{C}}=131.2\right), \mathrm{C}-2\left(\delta_{\mathrm{C}}=129.6\right), \mathrm{C}-6$ $\left(\delta_{\mathrm{C}}=126.8\right), \mathrm{C}-8\left(\delta_{\mathrm{C}}=138.1\right)$, from $5-\mathrm{H}$ to $\mathrm{C}-3\left(\delta_{\mathrm{C}}=128.9\right)$ and $\mathrm{C}-4\left(\delta_{\mathrm{C}}=151.9\right)$, and from $2-\mathrm{H}\left(\delta_{\mathrm{H}}=6.99\right)$ to $\mathrm{C}-4$ established the 

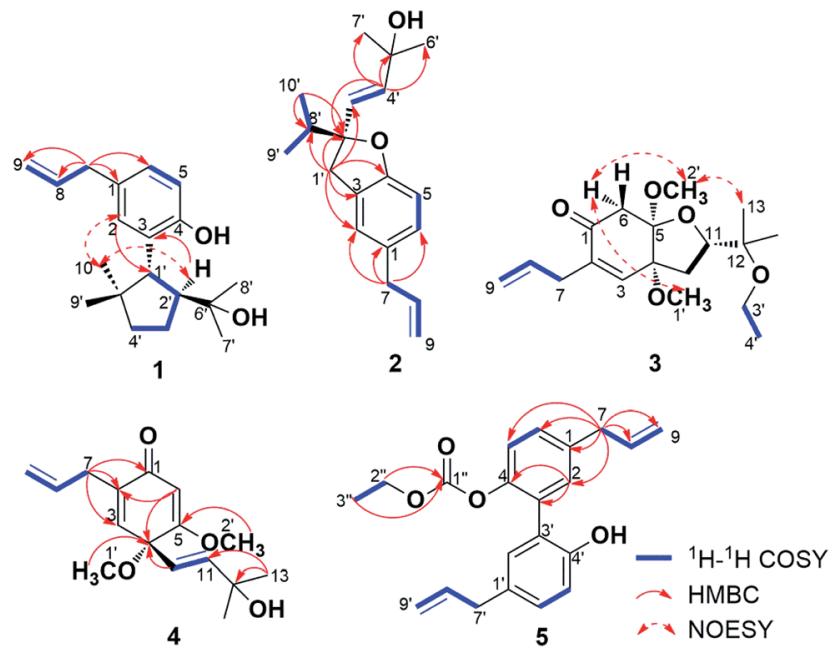

Fig. 2 Key ${ }^{1} \mathrm{H}-{ }^{1} \mathrm{H}$ COSY, HMBC and NOESY correlations of compounds $1-5$.

established the phenylpropene moiety in 1. Additionally, the spin coupling system $1^{\prime}-\mathrm{H} / 2^{\prime}-\mathrm{H} / 3^{\prime}-\mathrm{H}_{2} / 4^{\prime}-\mathrm{H}_{2}$ was also established on the basis of their mutual ${ }^{1} \mathrm{H}-{ }^{1} \mathrm{H}$ COSY correlations. Observation of $\mathrm{HMBC}$ correlations from $9^{\prime}-\mathrm{H}_{3}\left(\delta_{\mathrm{H}}=0.97\right)$ and $10^{\prime}-\mathrm{H}_{3}$ $\left(\delta_{\mathrm{H}}=0.74\right)$ to $\mathrm{C}-1^{\prime}\left(\delta_{\mathrm{C}}=47.4\right), \mathrm{C}-4^{\prime}\left(\delta_{\mathrm{C}}=41.6\right), \mathrm{C}-5^{\prime}\left(\delta_{\mathrm{C}}=43.9\right)$, and $7^{\prime}-\mathrm{H}_{3}\left(\delta_{\mathrm{H}}=1.13\right)$ and $8^{\prime}-\mathrm{H}_{3}\left(\delta_{\mathrm{H}}=0.99\right)$ to $\mathrm{C}-2^{\prime}\left(\delta_{\mathrm{C}}=54.3\right), \mathrm{C}-$ $6^{\prime}\left(\delta_{\mathrm{C}}=73.7\right)$ established an allo-thujane monoterpenoid moiety. A connection between $\mathrm{C}-3$ and $\mathrm{C}-\mathrm{1}^{\prime}$ was proved on the basis of the key HMBC correlations of $2-\mathrm{H}$ with $\mathrm{C}-1^{\prime}$, and $2^{\prime}-\mathrm{H}$ $\left(\delta_{\mathrm{H}}=2.47\right)$ with $\mathrm{C}-3$. Considering the molecular formula, there were two additional hydroxyls in $\mathbf{1}$, and they were supposed to locate at C-4 and C-6 $6^{\prime}$ positions based on the ${ }^{13} \mathrm{C}$ NMR chemical shift. Strong NOESY correlations of $10^{\prime}-\mathrm{H}_{3}$ with $2-\mathrm{H}$, and $1^{\prime}-\mathrm{H}$ $\left(\delta_{\mathrm{H}}=3.19\right)$ with $7^{\prime}-\mathrm{H}_{3}, 8^{\prime}-\mathrm{H}_{3}, 9^{\prime}-\mathrm{H}_{3}$ established the relative configuration of $\mathbf{1}$. Therefore, the structure of $\mathbf{1}$ was established, and named burmaniol A (Fig. 2).

Compound 2 was isolated as colorless oil. The HREIMS data at $m / z 286.1931[\mathrm{M}]^{+\cdot}$ (calcd 286.1933) established its molecular formula of $\mathrm{C}_{19} \mathrm{H}_{26} \mathrm{O}_{2}$, suggesting seven degrees of unsaturation. The ${ }^{1} \mathrm{H}$ NMR spectrum displayed the presence of two singlet methyl groups at $\delta_{\mathrm{H}}=1.27(3 \mathrm{H}, \mathrm{s}), 1.30(3 \mathrm{H}, \mathrm{s})$, an isopropyl group at $\delta_{\mathrm{H}}=0.96(6 \mathrm{H}, \mathrm{d}, J=6.5 \mathrm{~Hz}), 2.00(1 \mathrm{H}, \mathrm{sept}, J=6.5 \mathrm{~Hz})$, an allyl group at $\delta_{\mathrm{H}}=3.29(2 \mathrm{H}, \mathrm{d}, J=6.5 \mathrm{~Hz}), 5.03(1 \mathrm{H}, \mathrm{dd}, J=$ 10.0, 2.0 Hz), 5.06 (1H, dd, $J=17.0,2.0 \mathrm{~Hz}$ ), 5.95 (1H, ddt, $J=$ $17.0,10.0,6.5 \mathrm{~Hz})$, a trans-double bond at $\delta_{\mathrm{H}}=5.75(1 \mathrm{H}, \mathrm{d}, J=$ $15.5 \mathrm{~Hz}), 5.88(1 \mathrm{H}, \mathrm{d}, J=15.5 \mathrm{~Hz})$, and a 1,2,4-trisubstituted phenyl group at $\delta_{\mathrm{H}}=6.69(1 \mathrm{H}, \mathrm{d}, J=8.0 \mathrm{~Hz}), 6.91(1 \mathrm{H}, \mathrm{d}, J=8.0$ $\mathrm{Hz}), 6.93(1 \mathrm{H}, \mathrm{s})$. More detailed information about the structure of 2 came from the interpretation of ${ }^{1} \mathrm{H}-{ }^{1} \mathrm{H}$ COSY, HSQC, and HMBC spectra. Part of the NMR spectra of 2 strongly resembled to those of $\mathbf{1}$, indicating that it also has a propen-2-ylphenyl. Additionally, two spin coupling systems of $3^{\prime}-\mathrm{H} / 4^{\prime}-\mathrm{H}$ and $9^{\prime}-$ $\mathrm{H}_{3} / 8^{\prime}-\mathrm{H} / 10^{\prime}-\mathrm{H}_{3}$ were also established on the basis of their mutual ${ }^{1} \mathrm{H}-{ }^{1} \mathrm{H}$ COSY correlations. Further observation of HMBC correlations from $9^{\prime}-\mathrm{H}_{3}\left(\delta_{\mathrm{H}}=0.96\right), 10^{\prime}-\mathrm{H}_{3}\left(\delta_{\mathrm{H}}=0.96\right)$ to $\mathrm{C}-2^{\prime}\left(\delta_{\mathrm{C}}\right.$ $=92.3)$ and $\mathrm{C}-8^{\prime}\left(\delta_{\mathrm{C}}=37.1\right)$, from $1^{\prime}-\mathrm{H}_{2}\left(\delta_{\mathrm{H}}=3.00,3.18\right)$ to $\mathrm{C}-2^{\prime}$, $\mathrm{C}-3^{\prime}\left(\delta_{\mathrm{C}}=128.0\right)$ and $\mathrm{C}-8^{\prime}$, as well as the correlations from $4^{\prime}-\mathrm{H}$
$\left(\delta_{\mathrm{H}}=5.88\right)$ to $\mathrm{C}-2^{\prime}, \mathrm{C}-5^{\prime}\left(\delta_{\mathrm{C}}=70.8\right), \mathrm{C}-6^{\prime}, 7^{\prime}\left(\delta_{\mathrm{C}}=29.9\right)$ established a lavandulane monoterpenoid fragment. The monoterpenoid fragment was supposed to link to C-3 on the basis of the key HMBC correlations of $1^{\prime}-\mathrm{H}_{2}$ with C-2 $\left(\delta_{\mathrm{C}}=124.9\right), \mathrm{C}-3\left(\delta_{\mathrm{C}}\right.$ $=126.5), \mathrm{C}-4\left(\delta_{\mathrm{C}}=157.7\right)$, and $2-\mathrm{H}\left(\delta_{\mathrm{H}}=6.93\right)$ with $\mathrm{C}-1^{\prime}\left(\delta_{\mathrm{C}}=\right.$ 38.4). Deducting six degrees of unsaturation accounted for one phenyl group and two double bonds, the remaining one degree of unsaturation suggested that an additional ring was required. On the basis of the chemical shift, C-2' was supposed to link with $\mathrm{C}-4$ through an oxygen atom, forming a furan ring. Thus the planar structure of 2 was established as depict, and named burmaniol B. The absolute configuration of the sole C-2' chiral carbon was determined to be $S$ by comparison of its specific rotation value with $(S)$-2-ethenyl-2-methyl-2,3-dihydrobenzofuran reported in literature. ${ }^{30}$

Compound 3 was obtained as colorless oil, and its molecular formula of $\mathrm{C}_{18} \mathrm{H}_{28} \mathrm{O}_{5}$ was indicated by HRESIMS at $\mathrm{m} / \mathrm{z}=$ 347.1854 $[\mathrm{M}+\mathrm{Na}]^{+}$(calcd 347.1834). The ${ }^{1} \mathrm{H}$ NMR spectrum showed signals attributed to four singlet methyls at $\delta_{\mathrm{H}}=1.09$ $(3 \mathrm{H}, \mathrm{s}), 1.12(3 \mathrm{H}, \mathrm{s}), 3.37(3 \mathrm{H}, \mathrm{s}), 3.39(3 \mathrm{H}, \mathrm{s})$, an ethoxyl group at $\delta_{\mathrm{H}}=1.11(3 \mathrm{H}, \mathrm{t}, J=7.0 \mathrm{~Hz}), 3.40(2 \mathrm{H}, \mathrm{q}, J=7.0 \mathrm{~Hz})$, an isolated methylene group at $\delta_{\mathrm{H}}=2.57(1 \mathrm{H}, \mathrm{d}, J=16.5 \mathrm{~Hz}), 3.21(1 \mathrm{H}, \mathrm{d}$, $J=16.5 \mathrm{~Hz})$, an allyl group at $\delta_{\mathrm{H}}=3.04(1 \mathrm{H}, \mathrm{dd}, J=7.0,1.0 \mathrm{~Hz})$, $3.05(1 \mathrm{H}, \mathrm{dd}, J=7.0,1.0 \mathrm{~Hz}), 5.09(1 \mathrm{H}, \mathrm{dd}, J=17.0,1.0 \mathrm{~Hz}), 5.11$ $(1 \mathrm{H}, \mathrm{dd}, J=10.0,1.0 \mathrm{~Hz}), 5.82(1 \mathrm{H}, \mathrm{ddt}, J=17.0,10.0,7.0 \mathrm{~Hz})$, and a tri-substituted double bond at $\delta_{\mathrm{H}}=6.39(1 \mathrm{H}, \mathrm{s})$. The above spectroscopic data strongly resembled to those of 2,3dehydro-4,5-di-O-methyl-illifunone $\mathrm{E}$ isolated from Illicium anisatum ${ }^{5}$ except for an additional ethoxyl group $\left(\delta_{\mathrm{H}}=1.11\right.$, $\left.3.40 ; \delta_{\mathrm{C}}=16.2,57.0\right)$ in 3 . The ethoxyl group was supposed to attach at C-12 on the basis of the HMBC correlations of $3^{\prime}-\mathrm{H}_{2}\left(\delta_{\mathrm{H}}\right.$ $=3.40)$ and $4^{\prime}-\mathrm{H}_{3}\left(\delta_{\mathrm{H}}=1.11\right)$ with $\mathrm{C}-12\left(\delta_{\mathrm{H}}=75.4\right)$. The relative configuration of 3 was established based on the NOESY correlations of $6 \alpha-\mathrm{H}\left(\delta_{\mathrm{H}}=2.57\right)$ with $1^{\prime}-\mathrm{H}_{3}\left(\delta_{\mathrm{H}}=3.37\right)$ and $2^{\prime}-\mathrm{H}_{3}\left(\delta_{\mathrm{H}}=\right.$ $3.39)$, and $2^{\prime}-\mathrm{H}_{3}$ with $13-\mathrm{H}_{3}\left(\delta_{\mathrm{H}}=1.12\right)$. The absolute configuration of 3 was determined to be $4 R, 5 R, 11 S$ when compared its $\mathrm{CD}$ spectrum with illicinone $\mathrm{E}$ and 4-epi-illicinone E-12shikimate at $320 \mathrm{~nm}$ (Fig. S23†). ${ }^{2,7}$ Thus, the structure of 3 was identified as $(4 R, 5 R, 11 S)$-2,3-dehydro-4,5-di- $O$-methyl-12-Oethyl-illifunone E.

Compound 4 was obtained as colorless oil, and its molecular formula of $\mathrm{C}_{16} \mathrm{H}_{22} \mathrm{O}_{4}$ was indicated by HRESIMS at $\mathrm{m} / \mathrm{z}=$ 279.1597 $[\mathrm{M}+\mathrm{H}]^{+}$(calcd 279.1596). The ${ }^{1} \mathrm{H}$ NMR spectrum showed signals attributed to four singlet methyls at $\delta_{\mathrm{H}}=1.27$ $(6 \mathrm{H}, \mathrm{s}), 3.13(3 \mathrm{H}, \mathrm{s}), 3.74(3 \mathrm{H}, \mathrm{s})$, an allyl group at $\delta_{\mathrm{H}}=3.02(1 \mathrm{H}$, ddd, $J=16.0,7.0,1.0 \mathrm{~Hz}), 3.09$ (1H, ddd, $J=16.0,7.0,1.0 \mathrm{~Hz}$ ), $5.07(2 \mathrm{H}, \mathrm{m}), 5.81(1 \mathrm{H}, \mathrm{ddt}, J=18.0,10.0,7.0 \mathrm{~Hz})$, a trans double bond at $\delta_{\mathrm{H}}=5.58(1 \mathrm{H}, \mathrm{d}, J=16.0 \mathrm{~Hz}), 5.94(1 \mathrm{H}, \mathrm{d}, J=16.0 \mathrm{~Hz})$, and two tri-substituted double bonds at $\delta_{\mathrm{H}}=5.64(1 \mathrm{H}, \mathrm{s}), 6.15$ $(1 \mathrm{H}, \mathrm{br} \mathrm{s})$. The above spectroscopic data exhibited great similarity to illicinone $\mathrm{G}$ isolated from Illicium tashiroi. ${ }^{3}$ The differences between them was the absence of the methylenedioxy $\left(\delta_{\mathrm{H}}=5.41\right.$, $\left.5.60 ; \delta_{\mathrm{C}}=97.7\right)$, and these signals were replaced by two new emerged methoxyl groups $\left(\delta_{\mathrm{H}}=3.13,3.74 ; \delta_{\mathrm{C}}=52.4,56.1\right)$ in 4 . The HMBC correlations of $1^{\prime}-\mathrm{H}_{3}\left(\delta_{\mathrm{H}}=3.13\right)$ with $\mathrm{C}-4\left(\delta_{\mathrm{C}}=76.5\right)$ and $2^{\prime}-\mathrm{H}_{3}\left(\delta_{\mathrm{H}}=3.74\right)$ with $\mathrm{C}-5\left(\delta_{\mathrm{C}}=172.8\right)$ attributed the positions of the two methoxyl groups to be at C-4 and C-5, 
respectively. Thus, the structure of 4 was identified as 4,5-dimethoxyillicinone $\mathrm{G}$.

Compound 5 was isolated as yellow oil. Its molecular formula was established as $\mathrm{C}_{21} \mathrm{H}_{22} \mathrm{O}_{4}$ on the basis of its positive HRESIMS peak at $m / z=356.1862\left[\mathrm{M}+\mathrm{NH}_{4}\right]^{+}$(calcd 356.1862). The ${ }^{1} \mathrm{H}$ NMR spectrum of $\mathbf{5}$ showed signals attributed to an ethoxyl group at $\delta_{\mathrm{H}}=1.16(3 \mathrm{H}, \mathrm{t}, J=7.0 \mathrm{~Hz}), 4.11(2 \mathrm{H}, \mathrm{q}, J=7.0$ $\mathrm{Hz})$, two allyl units at $\delta_{\mathrm{H}}=3.33(2 \mathrm{H}, \mathrm{d}, J=7.0 \mathrm{~Hz}), 3.42(2 \mathrm{H}, \mathrm{d}, J$ $=7.0 \mathrm{~Hz}), 5.09(4 \mathrm{H}, \mathrm{m}), 5.95(2 \mathrm{H}, \mathrm{m})$, and two 1,3,4-substituted phenyl groups at $\delta_{\mathrm{H}}=6.91(1 \mathrm{H}, \mathrm{d}, J=8.5 \mathrm{~Hz}), 6.96(1 \mathrm{H}, \mathrm{br} \mathrm{d}, J=$ $2.5 \mathrm{~Hz}), 7.07(1 \mathrm{H}, \mathrm{dd}, J=8.5,2.5 \mathrm{~Hz})$ and $\delta_{\mathrm{H}}=7.18(1 \mathrm{H}, \mathrm{d}, J=$ $8.5 \mathrm{~Hz}), 7.19(1 \mathrm{H}$, br d, $J=2.5 \mathrm{~Hz}), 7.25(1 \mathrm{H}, \mathrm{dd}, J=8.5,2.5 \mathrm{~Hz})$. The above spectroscopic data exhibited great similarities to the known compound magnolol, ${ }^{31}$ except that there was an additional ethoxycarboxyl group in 5. The existence of ethoxycarboxyl group was confirmed by the ${ }^{1} \mathrm{H}-{ }^{1} \mathrm{H}$ COSY correlation of $2^{\prime \prime}-\mathrm{H}_{2}\left(\delta_{\mathrm{H}}=4.11\right)$ with $3^{\prime \prime}-\mathrm{H}_{3}\left(\delta_{\mathrm{H}}=1.16\right)$ and HMBC correlation of $2^{\prime \prime}-\mathrm{H}_{2}$ and $3^{\prime \prime}-\mathrm{H}_{3}$ with $\mathrm{C}-1^{\prime \prime}\left(\delta_{\mathrm{C}}=153.7\right)$. According to the chemical shift of C-4 and C- $4^{\prime}$, the ethoxycarboxyl group was supposed to locate at C-4 position. Thus the structure of 5 was established and named 4-[(ethoxycarbonyl)oxy]magnolol.

The known compounds (6-11) were identified as isomagnolone (6) ${ }^{32}$ 1-(8-propenyl)-3-[3'-methoxy-1' -(8-propenyl)phenoxy]-4,5dimethoxybenzene (7, Fig. S48-S54 $\dagger$ ), ${ }^{33,34}$ dihydrocubebin (8), ${ }^{35}$ macranthol (9), ${ }^{36}$ dunnianol $(\mathbf{1 0}),{ }^{37}$ dehydrodieugenol B $(\mathbf{1 1})^{38}$ by comparison of their spectroscopic data with those reported previously. The isolated compounds (1-11) were evaluated for cytotoxic activity against human tumor cell lines A549 (non-smallcell lung cancer cells), HCT116 (human colon cancer cells), MDAMB-231 (human breast cancer cells), and HepG2 (human hepatocellular carcinoma cells) in vitro (Table 3 ). ${ }^{39}$ The results showed that compounds $\mathbf{1}$ and $\mathbf{2}$ displayed appreciable cytotoxic activity against A549 and HCT116 cell lines with $\mathrm{IC}_{50}$ values of 6.40-7.76 $\mu \mathrm{M}$, whereas compounds $\mathbf{9}$ and $\mathbf{1 0}$ only exhibited potent inhibition against A549, HCT116 and HepG2 cells with $\mathrm{IC}_{50}$ values of 9.46-15.07 $\mu \mathrm{M}$. Doxorubicin was employed as the positive control and its IC $_{50}$ values against A549, HCT116, MDA-MB-231 and HepG2 cells were $0.18 \pm 0.004,0.07 \pm 0.001,0.59 \pm 0.010$ and $0.06 \pm 0.001 \mu \mathrm{M}$, respectively.

\section{Conclusions}

The eleven compounds (1-11) isolated from I. burmanicum indicated that Illicium plants are rich in structurally diverse lignans, neolignans and prenylated phenylpropanoids. Among the five new compounds (1-5), burmaniols A (1) and B (2) were unique allo-thujane-phenylpropane and lavandulane-phenylpropane hetero-adducts, and compound 1 contains a new furan ring formed through $\mathrm{C}-2^{\prime}$ and C-4. Compound 5 had an ethoxycarboxyl group at C-4 position, and the organic carbonates was

Table $1{ }^{1} \mathrm{H}$ NMR $\left(500 \mathrm{MHz}\right.$ ) spectroscopic data for compounds $1-5$ in $\mathrm{CDCl}_{3}$ ( $\mathrm{J}$ in $\mathrm{Hz}$ within parenthesis)

\begin{tabular}{|c|c|c|c|c|c|}
\hline No. & 1 & 2 & 3 & 4 & 5 \\
\hline \multicolumn{6}{|l|}{1} \\
\hline 2 & 6.99 br s & $6.93 \mathrm{~s}$ & & & 6.96 br d (2.5) \\
\hline 3 & & & $6.39 \mathrm{br} \mathrm{s}$ & 6.15 br s & \\
\hline \multicolumn{6}{|l|}{4} \\
\hline 5 & $6.70 \mathrm{~d}(8.0)$ & $6.69 \mathrm{~d}(8.0)$ & & & $6.91 \mathrm{~d}(8.5)$ \\
\hline 6 & 6.85 dd $(8.0,1.5)$ & $6.91 \mathrm{~d}(8.0)$ & $2.57 \mathrm{~d}(16.5) 3.21 \mathrm{~d}(16.5)$ & $5.64 \mathrm{~s}$ & $7.07 \mathrm{dd}(8.5,2.5)$ \\
\hline \multirow[t]{2}{*}{7} & $3.29 \mathrm{~d}(6.5)$ & $3.29 \mathrm{~d}(6.5)$ & $3.04 \mathrm{dd}(7.0,1.0)$ & 3.02 ddd $(16.0,7.0,1.0)$ & $3.33 \mathrm{~d}(7.0)$ \\
\hline & & & $3.05 \mathrm{dd}(7.0,1.0)$ & 3.09 ddd $(16.0,7.0,1.0)$ & \\
\hline 8 & 5.95 ddt $(17.0,11.0,6.5)$ & $5.95 \mathrm{ddt}(17.0,10.0,6.5)$ & 5.82 ddt $(17.0,10.0,7.0)$ & $5.81 \operatorname{ddt}(18.0,10.0,7.0)$ & $5.95 \mathrm{~m}$ \\
\hline \multirow[t]{2}{*}{9} & $5.00 \mathrm{dd}(17.0,2.0)$ & $5.03 \mathrm{dd}(10.0,2.0)$ & 5.09 dd $(17.0,1.0)$ & $5.07 \mathrm{~m}$ & $5.09 \mathrm{~m}$ \\
\hline & 5.02 dd $(11.0,2.0)$ & 5.06 dd $(17.0,2.0)$ & $5.11 \mathrm{dd}(10.0,1.0)$ & & \\
\hline \multirow[t]{2}{*}{10} & & & 1.99 dd $(12.0,6.0)$ & $5.58 \mathrm{~d}(16.0)$ & \\
\hline & & & $2.53 \mathrm{dd}(12.0,11.0)$ & & \\
\hline 11 & & & 3.59 dd $(11.0,6.0)$ & $5.94 \mathrm{~d}(16.0)$ & \\
\hline \multicolumn{6}{|l|}{12} \\
\hline 13 & & & $1.12 \mathrm{~s}$ & $1.27 \mathrm{~s}$ & \\
\hline 14 & & & $1.09 \mathrm{~s}$ & $1.27 \mathrm{~s}$ & \\
\hline $1^{\prime}$ & $3.19 \mathrm{~d}(10.0)$ & $3.00 \mathrm{~d}(15.5), 3.18 \mathrm{~d}(15.5)$ & $3.37 \mathrm{~s}$ & $3.13 \mathrm{~s}$ & \\
\hline $2^{\prime}$ & $2.47 \mathrm{~m}$ & & $3.39 \mathrm{~s}$ & $3.74 \mathrm{~s}$ & 7.19 br d (2.5) \\
\hline $3^{\prime}$ & $1.69 \mathrm{~m}, 1.95 \mathrm{~m}$ & $5.75 \mathrm{~d}(15.5)$ & $3.40 \mathrm{q}(7.0)$ & & \\
\hline $4^{\prime}$ & $1.59 \mathrm{~m}$ & $5.88 \mathrm{~d}(15.5)$ & $1.11 \mathrm{t}(7.0)$ & & \\
\hline $5^{\prime}$ & & & & & $7.18 \mathrm{~d}(8.5)$ \\
\hline $6^{\prime}$ & & $1.27 \mathrm{~s}$ & & & 7.25 dd $(8.5,2.5)$ \\
\hline $7^{\prime}$ & $1.13 \mathrm{~s}$ & $1.30 \mathrm{~s}$ & & & $3.42 \mathrm{~d}(7.0)$ \\
\hline $8^{\prime}$ & $0.99 \mathrm{~s}$ & 2.00 sept $(6.5)$ & & & $5.95 \mathrm{~m}$ \\
\hline $9^{\prime}$ & $0.97 \mathrm{~s}$ & $0.96 \mathrm{~d}(6.5)$ & & & $5.09 \mathrm{~m}$ \\
\hline $10^{\prime}$ & $0.74 \mathrm{~s}$ & $0.96 \mathrm{~d}(6.5)$ & & & \\
\hline $2^{\prime \prime}$ & & & & & $4.11 \mathrm{q}(7.0)$ \\
\hline $3^{\prime \prime}$ & & & & & $1.16 \mathrm{t}(7.0)$ \\
\hline
\end{tabular}


encountered very rarely. These new compounds add to the current list of miscellaneous constituents isolated from the Illicium genus. MTT assay indicated that compounds $\mathbf{1}$ and $\mathbf{2}$ have appreciable cytotoxicity against A549 and HCT 116 cells, while initial evaluation of the anti-tumor efficacy of these compounds is not enough, further studies are necessary for understanding their cytotoxic mechanisms.

\section{Experimental section}

\section{General}

1D and 2D NMR spectral data were obtained on a Bruker Avance III $500 \mathrm{MHz}$ NMR spectrometer (Bruker, Fallanden, Switzerland) with TMS as internal standard. HRESIMS spectra were measured on an Agilent 6520 Accurate-MS Q-TOF LC/MS system (Agilent Technologies, Santa Clara, CA, USA). HREIMS spectra were measured on Autospec-Ultima ETOF MS spectrometer (Micromass Ltd., Wythenshawe, Manchester, UK). Optical rotations were recorded on a Perkin-Elmer 341 digital polarimeter and CD spectra were recorded on a JASCO-J-810 spectrometer (JASCO Perkin-Elmer, Maryland, USA). Reversed phase medium pressure liquid chromatography (RP-MPLC) was performed on a Büchi Sepacore system (Büchi Labortechnik AG, Flawil, Switzerland). Materials for column chromatography were silica gel (100-200, 200-300 mesh, Huiyou Silica Gel Development Co. Ltd, Yantai, P. R. China), YMC-GEL ODS-A (50 $\mu \mathrm{m}$, Milford, Massachusetts, USA) and Sephadex LH-20 (40-70 $\mu \mathrm{m}$, Amersham Pharmacia Biotech AB, Uppsala, Sweden). All chemicals and solvents were analytical or high-performance liquid chromatography grade.

\section{Plant material}

The branches and leaves of Illicium burmanicum were collected in Gongshan county, Yunnan province, P. R. China, in September 2011, and authenticated by Prof. Han-Ming Zhang from Second Military Medical University. A voucher specimen (no. 20110925) is deposited in School of Pharmacy, Second Military Medical University.

\section{Extraction and isolation}

Air-dried branches and leaves of Illicium burmanicum $(20.0 \mathrm{~kg}$ ) were powdered and extracted with 95\% EtOH (80 L) three times (1 h) under condition of reflux. The solvent was removed under low pressure to afford a crude extract $(1.2 \mathrm{~kg})$, which was then suspended in water and extracted with petroleum ether (442 g), $\mathrm{CH}_{2} \mathrm{Cl}_{2}$ (188 g), EtOAc (120 g) and $n$-BuOH (155 g) successively. The petroleum ether $(\mathrm{PE})$ extract was subjected to silica gel column chromatography $(\mathrm{CC})(\phi 10 \times 120 \mathrm{~cm}, 100-200$ mesh, 2.6 $\mathrm{kg})$ and eluted with PE/EtOAc $(100: 1-0: 1)$ to give seven fractions [Fr. 1 (102 g), Fr. 2 (31 g), Fr. 3 (53 g), Fr. 4 (48 g), Fr. 5 (46 g), Fr. 6 (42 g), Fr. 7 (54 g)] based on TLC analysis. Fraction 3 was subjected to silica gel CC $(\phi 4.5 \times 100 \mathrm{~cm}, 200-300$ mesh, $1.0 \mathrm{~kg})$ and eluted with PE/EtOAc $(20: 1-0: 1)$ to afford eleven subfractions (Fr. 3-1-Fr. 3-11). Subfraction 3-4 (6.5 g) was subjected to Sephadex LH-20 CC $(\phi 5.0 \times 120 \mathrm{~cm})$ using $\mathrm{CH}_{2} \mathrm{Cl}_{2} / \mathrm{MeOH}(1: 1)$ elution to give compounds 4 (12.7 mg), 8 (15.3 mg), and 9 (7.0 mg). Subfraction 3-9 (3.2 g) was also passed over Sephadex LH-20 CC $(\phi 5.0 \times 120 \mathrm{~cm})$ using $\mathrm{CH}_{2} \mathrm{Cl}_{2} / \mathrm{MeOH}(1: 1)$ to give compounds 7 (31.0 mg) and $10(6.3 \mathrm{mg})$. Fraction 5 was subjected to $\mathrm{RP}-\mathrm{MPLC}\left(\phi 6.0 \times 50 \mathrm{~cm}, \mathrm{MeOH} / \mathrm{H}_{2} \mathrm{O}, 40-100 \%, 15 \mathrm{~mL} \mathrm{~min}^{-1}\right)$ to give eight subfractions (Fr. 5-1-Fr. 5-8). Subfraction 5-2 (8.1 g) was applied to silica gel CC $(\phi 4.5 \times 100 \mathrm{~cm}, 200-300$ mesh, 800 $\mathrm{g})$ and eluted with PE/EtOAc $(10: 1-0: 1)$ to give compounds 1 (4.2 $\mathrm{mg})$ and 2 (18.5 mg). Subfraction 5-5 (2.1 g) was passed over Sephadex LH-20 CC $(\phi 3.0 \times 150 \mathrm{~cm})$ using $\mathrm{CH}_{2} \mathrm{Cl}_{2} / \mathrm{MeOH}(1: 1)$ elution to give compounds $3(28.0 \mathrm{mg})$ and $11(7.2 \mathrm{mg})$. Compounds 5 (34 mg) and $6(3.6 \mathrm{mg})$ were isolated from subfraction 5-8 (2.6 g) by applying to RP-MPLC $(\phi 3.5 \times 50 \mathrm{~cm})$ and eluted with a gradient of $\mathrm{MeOH} / \mathrm{H}_{2} \mathrm{O}\left(40-100 \%, 15 \mathrm{~mL} \mathrm{~min}{ }^{-1}\right)$.

Burmaniol A (1). White wax; $[\alpha]_{\mathrm{D}}^{20}+114.0(c 0.10, \mathrm{MeOH})$; CD (c $\left.0.13 \mathrm{mg} \mathrm{mL}^{-1}, \mathrm{MeOH}, 20^{\circ} \mathrm{C}\right) \mathrm{nm}(\Delta \varepsilon) 210(-3.98), 233(+2.84)$, 288 (-0.65); HRESIMS $m / z$ 287.2022 [M - H] $]^{-}$(calcd 287.2011); ${ }^{1} \mathrm{H}-\mathrm{NMR}$ and ${ }^{13} \mathrm{C}-\mathrm{NMR}$ data for 1 , see Tables 1 and 2.

$\left(2^{\prime} S\right)$-Burmaniol B (2). Colorless oil; $[\alpha]_{\mathrm{D}}^{20}-11.7$ (c 0.30, $\mathrm{MeOH}) ; \mathrm{CD}\left(c 0.50 \mathrm{mg} \mathrm{mL}{ }^{-1}, \mathrm{MeOH}, 20{ }^{\circ} \mathrm{C}\right) \mathrm{nm}(\Delta \varepsilon) 199(+8.59)$; HREIMS $m / z$ 286.1931 [M] ${ }^{+}$(calcd 286.1933); ${ }^{1} \mathrm{H}-\mathrm{NMR}$ and ${ }^{13} \mathrm{C}$ NMR data for 2, see Tables 1 and 2 .

(4R,5R,11S)-2,3-Dehydro-4,5-di-O-methyl-12-O-ethyl-illifunone E (3). Colorless oil; $[\alpha]_{\mathrm{D}}^{20}-40.0(c 0.50, \mathrm{MeOH})$; CD $(c 0.50 \mathrm{mg}$ $\left.\mathrm{mL}^{-1}, \mathrm{MeOH}, 20{ }^{\circ} \mathrm{C}\right) \mathrm{nm}(\Delta \varepsilon) 245$ (+8.79), 317 (-1.12); HREIMS $\mathrm{m} / \mathrm{z}$ 347.1854 [M + Na $]^{+}$(calcd 347.1834); ${ }^{1} \mathrm{H}-\mathrm{NMR}$ and ${ }^{13} \mathrm{C}-\mathrm{NMR}$ data for 3 , see Tables 1 and 2 .

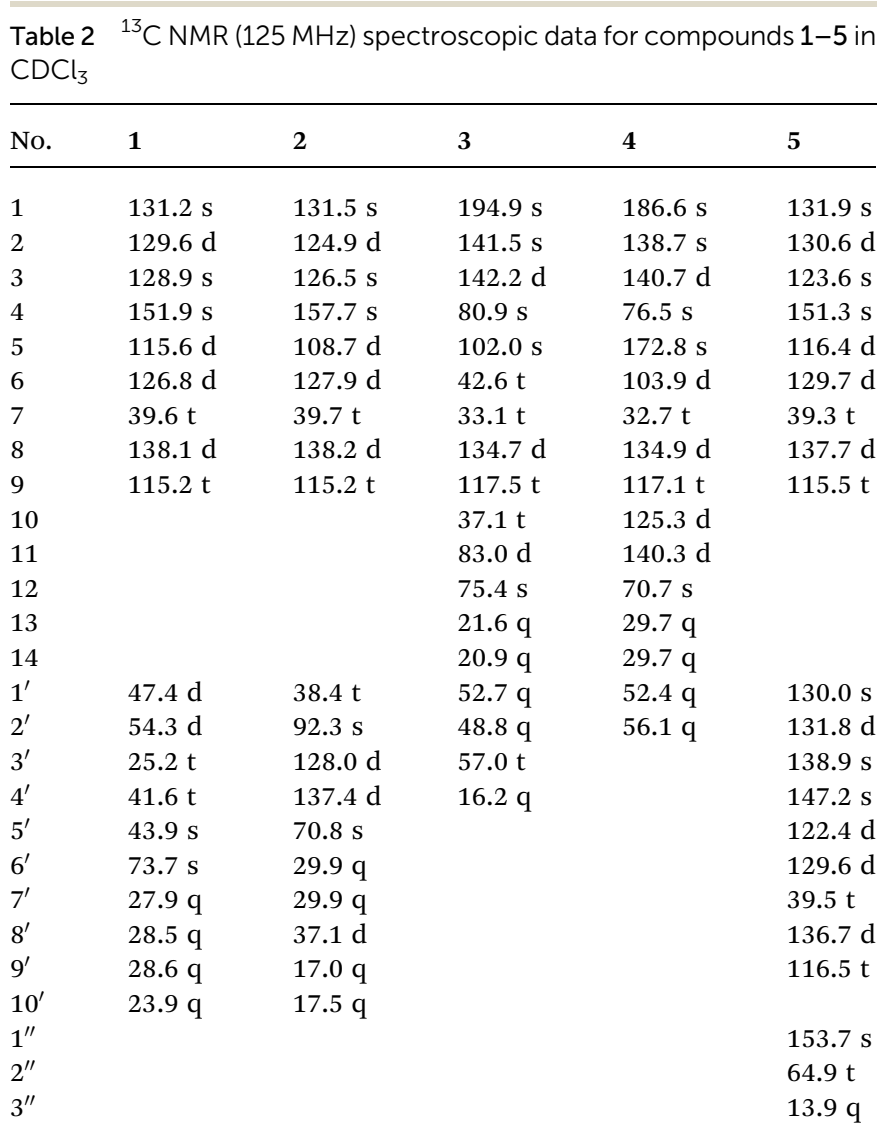


Table 3 Cytotoxicity data for compounds 1, 2, 9, and $10^{a}$

\begin{tabular}{|c|c|c|c|c|}
\hline Compounds & \multicolumn{4}{|l|}{$\mathrm{IC}_{50}(\mu \mathrm{M})$} \\
\hline 2 & $6.40 \pm 0.12$ & $7.18 \pm 0.08$ & $28.66 \pm 0.27$ & $12.88 \pm 0.17$ \\
\hline 9 & $9.46 \pm 0.18$ & $10.86 \pm 0.15$ & $17.30 \pm 0.31$ & $13.64 \pm 0.13$ \\
\hline 10 & $12.91 \pm 0.24$ & $15.07 \pm 0.29$ & $30.72 \pm 0.66$ & $13.49 \pm 0.25$ \\
\hline
\end{tabular}

4,5-Dimethoxyillicinone G (4). Colorless oil; $[\alpha]_{\mathrm{D}}^{20}-16.7(c$ 0.30, $\mathrm{MeOH})$; $\mathrm{CD}\left(c 0.10 \mathrm{mg} \mathrm{mL}{ }^{-1}, \mathrm{MeOH}, 20{ }^{\circ} \mathrm{C}\right) \mathrm{nm}(\Delta \varepsilon) 264$ (-6.44), $330(+1.67)$; HREIMS $m / z 279.1597[\mathrm{M}+\mathrm{H}]^{+}$(calcd 279.1596); ${ }^{1} \mathrm{H}-\mathrm{NMR}$ and ${ }^{13} \mathrm{C}-\mathrm{NMR}$ data for 4 , see Tables 1 and 2 .

4-[(Ethoxycarbonyl)oxy] magnolol (5). Yellow oil; HREIMS $\mathrm{m} / \mathrm{z}$ 356.1862 $\left[\mathrm{M}+\mathrm{NH}_{4}\right]^{+}$(calcd 356.1862); ${ }^{1} \mathrm{H}-\mathrm{NMR}$ and ${ }^{13} \mathrm{C}-\mathrm{NMR}$ data for 5 , see Tables 1 and 2 .

1-(8-Propenyl)-3-[3'-methoxy-1'-(8-propenyl)phenoxy]-4,5-dimethoxybenzene (7). Colorless oil; ESIMS $m / z=363[\mathrm{M}+\mathrm{Na}]^{+}$, $703[2 \mathrm{M}+\mathrm{Na}]^{+} ;{ }^{1} \mathrm{H}$ NMR $\left(500 \mathrm{MHz}, \mathrm{CDCl}_{3}\right) \delta: 6.28(1 \mathrm{H}, \mathrm{d}, J=$ $2.0 \mathrm{~Hz}, \mathrm{H}-2), 6.48(1 \mathrm{H}, \mathrm{d}, J=2.0 \mathrm{~Hz}, \mathrm{H}-6), 3.24(2 \mathrm{H}, \mathrm{d}, J=6.5 \mathrm{~Hz}$, $\mathrm{H}-7), 5.88$ (1H, m, H-8), 5.04 (2H, m, H-9), $6.81(1 \mathrm{H}, \mathrm{d}, J=2.0 \mathrm{~Hz}$, $\left.\mathrm{H}-2^{\prime}\right), 6.82\left(1 \mathrm{H}, \mathrm{d}, J=10.0 \mathrm{~Hz}, \mathrm{H}-5^{\prime}\right), 6.70(1 \mathrm{H}, \mathrm{dd}, J=8.0,2.0 \mathrm{~Hz}$, H-6 $\left.6^{\prime}\right), 3.37\left(2 \mathrm{H}, \mathrm{d}, J=7.0 \mathrm{~Hz}, \mathrm{H}-7^{\prime}\right), 5.98\left(1 \mathrm{H}, \mathrm{m}, \mathrm{H}-8^{\prime}\right), 5.10(2 \mathrm{H}$, $\left.\mathrm{m}, \mathrm{H}-9^{\prime}\right), 3.87\left(3 \mathrm{H}, \mathrm{s}, 4-\mathrm{OCH}_{3}\right), 3.86\left(3 \mathrm{H}, \mathrm{s}, 5-\mathrm{OCH}_{3}\right), 3.82(3 \mathrm{H}, \mathrm{s}$, $\left.3^{\prime}-\mathrm{OCH}_{3}\right) .{ }^{13} \mathrm{C}$ NMR (125 MHz, $\left.\mathrm{CDCl}_{3}\right) \delta: 135.5(\mathrm{C}-1), 111.4(\mathrm{C}-2)$, 150.6 (C-3), 138.1 (C-4), 153.5 (C-5), 107.3 (C-6), 40.1 (C-7), 137.1

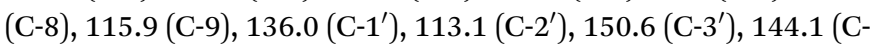
$\left.4^{\prime}\right), 119.4\left({\mathrm{C}-5^{\prime}}^{\prime}\right), 120.8\left(\mathrm{C}-6^{\prime}\right), 39.9\left(\mathrm{C}^{\prime} 7^{\prime}\right), 137.4\left(\mathrm{C}-8^{\prime}\right), 115.9\left(\mathrm{C}-9^{\prime}\right)$, $60.9\left(4-\mathrm{OCH}_{3}\right), 56.1\left(5-\mathrm{OCH}_{3}\right), 55.9\left(3^{\prime}-\mathrm{OCH}_{3}\right)$. See Fig. S48-S54. $\dagger$

\section{Chemicals and reagents for biological activities}

The human non-small-cell lung carcinoma cells (A549), human colon cancer cells (HCT116), human breast cancer cells (MDAMB-231), and human hepatocellular carcinoma cells (HepG2) were obtained from the Cell Bank of Shanghai Institute of Biochemistry \& Cell Biology, Shanghai Institute for Biological Sciences, Chinese Academy of Sciences; Dimethylsulfoxide (DMSO), 3-(4,5-dimethylthiazol-2-yl)-2,5-diphenyltetrazolium bromide (MTT), and doxorubicin were purchased from Sigma Chemical Co. (St. Louis, MO, USA).

\section{MTT assay}

The cytotoxicity of compounds against human non-small-cell lung carcinoma cells (A549), human colon cancer cells (HCT116), human breast cancer cells (MDA-MB-231), and human hepatocellular carcinoma cells (HepG2) was determined by MTT assay. ${ }^{39}$ The assay was performed in triplicate. All cells were seeded in 96well plate at a density of $10^{4}$ cells per well and incubated in a humidified $5 \% \mathrm{CO}_{2}$ atmosphere at $37{ }^{\circ} \mathrm{C}$ for $24 \mathrm{~h}$. Then the medium was removed, and each well was treated with $50 \mu \mathrm{L}$ of medium containing $0.2 \%$ DMSO (control group), or $1-100 \mu \mathrm{M}$ tested compounds, or the positive control doxorubicin. After $24 \mathrm{~h}$ of treatment, the medium was removed, and $20 \mu \mathrm{L}$ of MTT solution (5 $\mathrm{mg} \mathrm{mL}^{-1}$; Sigma; St. Louis, MO) was added to each well, and the cultures were incubated for another $3 \mathrm{~h}$ at $37^{\circ} \mathrm{C}$. Upon removal of MTT medium, $100 \mu \mathrm{L}$ of DMSO was added to each well and agitated at $60 \mathrm{rpm}$ for $5 \mathrm{~min}$ to dissolve the precipitate. The absorbance was measured at $570 \mathrm{~nm}$ by a SYNERGY microplate reader (Bio Tek, Winooski, VT). Doxorubicin was employed as the positive control and its IC $_{50}$ values against A549, HCT116, MDAMB-231, and HepG2 cells were $0.18 \pm 0.004,0.07 \pm 0.001,0.59$ \pm 0.010 and $0.06 \pm 0.001 \mu \mathrm{M}$, respectively.

\section{Acknowledgements}

The work was supported by Professor of Chang Jiang Scholars Program, NSFC (81230090, 81520108030, 81573318, 81373301, 1302658), Shanghai Engineering Research Center for the Preparation of Bioactive Natural Products (10DZ2251300), the Scientific Foundation of Shanghai China (12401900801, 13401900101), National Major Project of China (2011ZX09307002-03) and the National Key Technology R \& D Program of China (2012BAI29B06).

\section{References}

1 Y. H. Liu, X. R. Luo, R. F. Wu and B. N. Zhang, Flora Republicae Popularis Sinicae, Science Press, Beijing, 1996, vol. 30, pp. 199-231.

2 Y. Fukuyama, N. Shida, T. Sakurai and M. Kodama, Phytochemistry, 1992, 31, 3975-3979.

3 Y. Fukuyama, N. Shida, Y. Hata and M. Kodama, Phytochemistry, 1994, 36, 1497-1503.

4 Y. Fukuyama, K. Okamoto, Y. Kubo, N. Shida and M. Kodama, Chem. Pharm. Bull., 1994, 42, 2199-2201.

5 I. Kouno, S. Shimamoto, Z. H. Jiang and T. Tanaka, Phytochemistry, 1997, 46, 1389-1392.

6 Y. N. Liu, X. H. Su, C. H. Huo, X. P. Zhang, Q. W. Shi and Y. C. Gu, Chem. Biodiversity, 2009, 6, 963-989.

7 X. F. Wu, Y. Li, H. N. Lu, S. S. Yu, S. G. Ma and J. Liu, J. Asian Nat. Prod. Res., 2009, 12, 1056-1061.

8 Y. Z. He, E. K. Osoro, S. I. Palmer, L. N. Wang and N. S. Aboud, Chin. Herb. Med., 2014, 6, 76-79.

9 D. D. Huang, H. Y. Zhu, Y. H. Chen, W. S. Chen, D. Xue and L. N. Sun, Fitoterapia, 2015, 107, 22-28. 
10 Y. Fukuyama, N. Shida, M. Kodama, H. Chaki and T. Yugami, Chem. Pharm. Bull., 1995, 43, 2270-2272.

11 T. Nakamura, M. Okuyama and M. Yamazaki, Chem. Pharm. Bull., 1996, 44, 1908-1914.

12 Y. Fukuyama, Y. Hata and M. Kodama, Planta Med., 1997, 63, 275-277.

13 J. M. Huang, R. Yokoyama, C. S. Yang and Y. Fukuyama, Tetrahedron Lett., 2000, 41, 6111-6114.

14 J. M. Huang, R. Yokoyama, C. S. Yang and Y. Fukuyama, J. Nat. Prod., 2001, 64, 428-431.

15 R. Yokoyama, J. M. Huang, C. S. Yang and R. Fukuyama, J. Nat. Prod., 2002, 65, 527-531.

16 M. Moriyama, J. M. Huang, C. S. Yang, H. Hioki, M. Kubo, K. Harada and Y. Fukuyama, Tetrahedron, 2007, 63, 42434249.

17 M. Moriyama, J. M. Huang, C. S. Yang, M. Kubo, K. Harada, H. Hioki and Y. Fukuyama, Chem. Pharm. Bull., 2008, 56, 1201-1204.

18 M. Kubo, C. Okada, J. M. Huang, K. Harada, H. Hioki and Y. Fukuyama, Org. Lett., 2009, 22, 5190-5193.

19 M. Kubo, K. Kobayashi, J. M. Huang, K. Harada and Y. Fukuyama, Tetrahedron Lett., 2012, 53, 1231-1235.

20 S. Takaoka, N. Takaoka, Y. Minoshima, J. M. Huang, M. Kubo, K. Harada, H. Hioki and Y. Fukuyama, Tetrahedron, 2009, 65, 8354-8361.

21 J. Xu, M. H. Lacoske and E. A. Theodorakis, Angew. Chem., Int. Ed., 2014, 53, 956-987.

22 X. H. Tian, R. C. Yue, H. W. Zeng, H. L. Li, L. Shan, W. W. He, Y. H. Shen and W. D. Zhang, Sci. Rep., 2015, 5, 16982.

23 Y. Kudo, J. I. Oka and K. Yamada, Neurosci. Lett., 1981, 25, $83-88$.

24 X. H. Tian, L. Li, J. P. Pei, R. C. Yue, X. Fang, J. P. Zhang, W. W. He, L. Shan, Y. H. Shen and W. D. Zhang, RSC Adv., 2015, 5, 75857-75862.
25 M. Itoigawa, C. Ito, H. Tokuda, F. Enjo, H. Nishino and H. Furukawa, Cancer Lett., 2004, 214, 165-169.

26 D. D. Huang, H. P. Deng, W. S. Chen, G. H. Huang, C. Chen and L. N. Sun, Fitoterapia, 2014, 92, 194-199.

27 T. Matsui, C. Ito, M. Itoigawa, T. Okada and H. Furukawa, Planta Med., 2007, 73, 662-665.

28 J. Li, D. Geng, J. Xu, L. J. Weng, Q. Liu and L. T. Yi, Eur. J. Pharmacol., 2013, 707, 112-119.

29 J. P. Wang, Z. Y. Guan, C. F. Dong, L. Gao, S. D. Luo and Y. F. Wang, China J. Chin. Mater. Med., 2014, 39, 2526-2530.

30 Y. Uozumi, H. Kyota, K. Kato, M. Ogasawara and T. Hayashi, J. Org. Chem., 1999, 64, 1620-1625.

31 C. Q. Liang, X. L. Zhou, Z. Wang, X. J. Su and Q. Xu, Chin. Tradit. Pat. Med., 2010, 32, 824-827.

32 I. Kouno, C. Iwamoto, Y. Kameda, T. Tanaka and C. S. Yang, Chem. Pharm. Bull., 1994, 42, 112-114.

33 N. I. Baek, H. Kim, Y. H. Lee, J. D. Park, K. S. Kang and S. I. Kim, Planta Med., 1992, 58, 566-568.

34 T. A. D. Costa-Silva, S. S. Grecco, F. S. De Sousa, J. H. G. Lago, E. G. A. Martins, C. A. Terrazas, S. Varikuti, K. L. Owens, S. M. Beverley, A. R. Satoskar and A. G. Tempone, J. Nat. Prod., 2015, 78, 653-657.

35 B. J. Cabanillas, A. Le Lamer, D. Castillo, J. Arevalo, R. Rojas, G. Odonne, G. Bourdy, B. Moukarzel, M. Sauvain and N. Fabre, J. Nat. Prod., 2010, 73, 1884-1890.

36 P. J. Yin, J. S. Wang, P. R. Wang and L. Y. Kong, Chin. J. Nat. Med., 2012, 10, 383-387.

37 S. Yahara, T. Nishiyori, A. Kohda, T. Nohara and I. Nishioka, Chem. Pharm. Bull., 1991, 39, 2024-2036.

38 A. M. P. De Diaz, H. E. Gottlieb and O. R. Gottlieb, Phytochemistry, 1980, 19, 681-682.

39 X. H. Tian, R. C. Yue, S. D. Zhang, Y. H. Shen, J. Ye, L. Shan, H. L. Li, B. Wen, X. K. Xu and W. D. Zhang, Eur. J. Org. Chem., 2014, 4753-4758. 